\title{
PENGARUH ELEVASI KAKI TERHADAP PENURUNAN FOOT OEDEM PADA PENDERITA CONGESTIVE HEART FAILURE (CHF)
}

\section{THE EFFECT OF FOOT ELEVATION ON DECREASED FOOT EDEMA SUFFERERS OF CONGESTIVE HEART FAILURE (CHF)}

\author{
Kasron; Susilawati \\ STIKES Al-Irsyad Al-Islamiyyah Cilacap \\ Jln. Cerme No 24 Sidanegara Cilacap 53222 \\ kasron@stikesalirsyadclp.ac.id
}

\section{INFO}

\section{ARTIKEL}

Kata Kunci :

$\mathrm{CHF}$, foot oedema, foot elevation

Key Word:

$\mathrm{CHF}$, foot oedema, foot elevation

\section{ABSTRAK/ABSTRACT}

Foot oedema (FO) merupakan salah satu manisfestasi klinis pasien Congestive Heart Failure (CHF) yang sangat menggangu penderitanya seperti susah untuk berjalan dan beraktifitas. Tujuan penelitian untuk mengetahui pengaruh foot elevation terhadap penurunan FO. Metode penelitian menggunakan quasieksperiment dengan pendekatan pre-posttest with control group design. Responden adalah pasien CHF yang mengalami FO yang dibagi menjadi kelompok kontrol dan kelompok intervensi. Intervensi dilakukan dengan FE satu kali sehari selama 3 hari. Responden diukur lingkar FO pada lingkar Angkle, Instep dan Metatarsal. Analisis statistik menggunakan uji Wilcoxon dan MannWhitney. Sejumlah 48 responden memenuhi kriteria penelitian. Hasil pada kelompok intervensi menunjukan lingkar angkle, instep, metatarsal pada kaki kanan sebelum perlakuan dan hari ketiga dalam $\mathrm{cm}(27,8 \pm 1,8$ vs $27,2 \pm 1,7)$, $(27,7 \pm 1,7$ vs $27,0 \pm 1,7),(27,2 \pm 1,6$ vs $26,5 \pm 1,7)$ dan pada kaki kiri $(27,8 \pm 1,7$ vs $27,2 \pm 1,6)$, $(27,7 \pm 1,6$ vs $26,9 \pm 1,6)$, $(27,1 \pm 1,5$ vs $26,3 \pm 1,6)$ dan selisih lingkar angkle, instep, metatarsal hari ketiga kaki kanan $(0,52 \pm 0,31,0,65 \pm 0,17$, $0,77 \pm 0,17)$ kaki kiri $(0,59 \pm 0,18,0,72 \pm 0,13,0,74 \pm 0,41)$. Hasil analisis menunjukan bahwa ada perbedaan lingkar FO pada kelompok intervensi pada hari pertama, kedua dan ketiga, dan menunjukan ada perbedaan yang bermakna antara selisih lingkar FO ( $\triangle \mathrm{P} 0-\mathrm{P} 3)$ pada pengukuran lingkar $\mathrm{FO}$ sebelum intervensi dengan hari ketiga antara kelompok kontrol dan intervensi. Kesimpulan penelitian adalah proses FE kaki efektif menurunkan lingkar foot oedema pada pasien CHF. Perlu tindakan untuk penatalaksanaan FO dengan FE pada pasien yang mengalami FO.

Foot edema $(F O)$ is one of the clinical manifestations of Congestive Heart Failure (CHF) patients which is very disturbing for sufferers such as difficulty in walking and activities. The study is aim to determine the effect of foot elevation on FO reduction. The methods uses quasi-experiment with a preposttest with control group design approach. Respondents were CHF patients who had FO who were divided into a control group and an intervention group. The intervention was carried out with FE once a day for 3 days. Respondents were measured FO circumference on the Angkle, Instep and Metatarsal circles. Statistical analysis using the Wilcoxon and Mann-Whitney test. A total of 48 respondents met the research criteria. Results in the intervention group showed angkle, instep, and metatarsal circumference of the right foot before treatment and the third day in $\mathrm{cm}(27.8 \pm 1.8$ vs $27.2 \pm 1.7)$, (27.7 \pm 1.7 vs $27,0 \pm 1.7)$, 
$(27.2 \pm 1.6 v s 26.5 \pm 1.7)$ and on the left foot $(27.8 \pm 1.7 v s 27.2 \pm 1.6),(27.7 \pm$ 1.6 vs. $26.9 \pm 1.6),(27.1 \pm 1.5$ vs $26.3 \pm 1.6)$ and the difference between the angkle, instep, and metatarsal circumference of the third day of the right foot $(0.52 \pm 0,31,0.65 \pm 0.17,0.77 \pm 0.17)$ left foot $(0.59 \pm 0.18,0.72 \pm 0.13,0.74 \pm$ $0.41)$. The analysis showed that there was a difference in FO circumference in the intervention group on the first, second and third day, and showed a significant difference between the FO circumference $(\triangle P 0-P 3)$ in the measurement of the FO circumference before the intervention and the third day between the control and intervention groups. The conclusion of the study is that the foot FE process effectively reduces foot edema circumference in CHF patients. Action is needed for the management of FO with FE in patients experiencing $\mathrm{FO}$.

\section{A. PENDAhULUAN}

Congestive Heart Failure (CHF) adalah ketidakmampuan otot jantung memompakan sejumlah darah untuk memenuhi kebutuhan metabolik tubuh. CHF adalah sebuah kondisi dari kardiovaskuler dimana jantung tidak bisa memompa darah secara adekuat untuk memenuhi kebutuhan metabolisme dari jaringan tubuh (Desai et al., 2012). Beberapa faktor resiko gagal jantung adalah kebiasaan merokok, kurang aktivitas fisik, perubahan pola diet, kelebihan berat badan, hiperlipidemia, diabetes, hipertensi, usia, jenis kelamin dan keturunan. Berdasarkan penelitian diketahui penyebab utama CHF adalah hipertensi dan penyakit arteri koronaria. CHF merupakan tahap akhir dari seluruh penyakit jantung dan merupakan penyebab peningkatan morbiditas dan mortalitas pasien jantung. Berdasarkan data World Health Organisations (WHO) risiko kematian akibat gagal jantung berkisar antara $5-10 \%$ pertahun pada gagal jantung ringan yang akan meningkat menjadi 30$40 \%$ pada gagal jantung berat(World Health Organization (WHO), 2015).

Penyakit CHF meningkat sesuai dengan perkembangan usia, prevalensi CHF di dunia sekitar $1 \%$ pada orang yang berusia 50-59 tahun, $10 \%$ pada usia lebih dari 65 tahun, dan 50\% pada usia lebih dari 85 tahun. Pada negara berkembang prevalensi CHF sekitar 1-2\% dari populasi dewasa.
Prevalensi meningkat lebih dari $10 \%$ pada usia lebih dari 70 tahun. Prevalensi CHF di Indonesia adalah $0,13 \%$, tertinggi di Yogyakarta 0,25\%, disusul Jawa Timur 0,19\%, dan ketiga di Jawa Tengah $0,18 \%$. Berdasarkan jenis kelamin kejadian CHF pada laki-laki adalah $0,1 \%$ dan perempuan $0,2 \%$. Berdasarkan usia pasien kejadian CHF pada usia 15-34 tahun adalah $0,07 \%$, usia 35-54 tahun 0,28\%, 55-74 tahun 0,87\%, lebih dari 75 tahun $0,41 \%$. (Dinas Kesehatan Republik Indonesia, 2013).

Gejala penyakit CHF yang berkaitan dengan retensi cairan adalah nyeri epigastrik, distensi abdomen, ascites, oedem sakral dan oedem peripheral. Persentase gejala pada CHF adalah dispnoea (52\%), orthopnoea (81\%), paroxysmal nocturnal dyspnoea (76\%), foot oedema (FO) (80\%) (Panel et al., 2011).

Foot oedema didefinisikan sebagai akumulasi cairan di kaki dan tungkai yang di akibatkan oleh ekspansi volume interstisial atau peningkatan volume ekstraseluler. Foot oedema akan menyebabkan penurunan fungsi kesehatan dan kualitas hidup (HR-QOL), ketidaknyamanan, perubahan postur tubuh, menurunkan mobilitas dan meningkatkan resiko jatuh, gangguan sensasi di kaki dan menyebabkan 
perlukaan di kulit (Rahnavard, Nodeh and Hatamipour, 2014).

Penatalaksanaan non-farmakologi pada oedema bertujuan untuk mengurangi bengkak dengan cara meningkatkan pengeluaran cairan secara limfatik serta menurunkan distribusi cairan secara kapiler yaitu dengan exercise, elevation, graded external compresion (hosiery), dan pijat limfatik (Pozehl et al., 2010).

Foots elevation merupakan intervensi yang mudah dan sederhana yang dapat dilakukan untuk mengurangi gejala foot oedema. Namun intervensi tersebut jarang dilakukan untuk mengatasi gejala foot oedema tersebut. Dengan memberikan posisi kaki dinaikan akan meningkatkan jumlah volume dan aliran darah dan limfe kembali ke jantung (Man et al., 2004). Demikian juga dengan memberikan posisi kaki lebih tinggi akan meningkatkan sirkulasi aliran darah pada pembuluh kapiler bagian distal yang akan meningkatkan aliran darah ke bagian tubuh. (Park, Han and Kim, 2010)

Hasil penelitian sebelumnya oleh peneliti tentang pijat kaki yang dilakukan di RSUD Cilacap pada tahun 2018 diketahui jumlah kasus foot oedema pada CHF masih sangat tinggi, dimana $52,3 \%$ penderita FO pada perempuan, $47,7 \%$ berpendidikan SMP, dan 63,6\% pada CHF grade III (Kasron and Engkartini, 2018). Pada pasien CHF yang mengalami oedem kaki di RSUD Cilacap belum dilakukan penatalaksanaan terstandar keperawatan untuk mengurangi gejala oedem kaki tersebut. Dengan rencana penelitian ini diharapkan dapat diketahui pengaruh foot elevation terhadap penurunan foot oedema pada pasien Congestive Heart Failure (CHF).

\section{B. METODE}

Penelitian dilakukan di RSUD Cilacap, ruang penyakit dalam. Jenis penelitian quasi experimental, dengan pendekatan preposttest with control group design. Metline digunakan untuk mengukur lingkar FO yaitu pada lingkar Ankle, lingkar Instep, lingkar sendi MP (metatarsal-phalangs-joint). Pengambilan data dengan mengukur lingkar FO setelah tindakan pada hari ke-1,2 dan 3 . Intervensi elevasi kaki selama 3 hari dengan durasi \pm 20 menit. Pengambilan sample dengan purposive sampling dengan kriteria yang sudah ditetapkan yaitu: 1). Pasien gagal jantung stabil yang ditandai dengan: tidak ada nyeri dada, tidak sesak nafas saat istirahat, denyut nadi istirahat 50-90x/menit dan reguler, tekanan darah sistolik 100-150 $\mathrm{mmHg}$, dan tekanan darah diastolik 60-90 mmHg, 2). Bersedia menjadi responden. Sedangkan kriteria eksklusi sampel dalam penelitian ini adalah: 1). NYHA fungsional kelas IV, 2). Aritmia pada saat istirahat, 3). Denyut jantung saat istirahat lebih dari 100x/menit. Analisis menggunakan Wilcoxon test untuk mengetahui perbandingan lingkar FO antar pengukuran dalam satu kelompok dan Mann-Whitney test untuk mengetahui perbandingan lingkar FO antara kelompok control dan intervensi..

\section{HASIL}

Penelitian dilakukan pada sejumlah 13 pasien CHF yang mengalami oedem kaki dan sesuai dengan kriteria inklusi. Berikut deskripsi karakteristik responden penelitian.

Tabel 1

Deskripsi Karakteristik Pasien CHF

Yang Mengalami Oedem Kaki $(n=13)$

\begin{tabular}{llc}
\hline No & Variabel & Deskripsi \\
\hline 1 & Umur (tahun) & $54,23 \pm 5,8$ \\
2 & Jenis kelamin & \\
& Laki-laki & $8(61,5 \%)$
\end{tabular}




\begin{tabular}{|c|c|c|}
\hline \multirow{3}{*}{3} & Perempuan & $5(38,5 \%)$ \\
\hline & Pendidikan & \\
\hline & Tidak lulus & $1(7,7 \%)$ \\
\hline & SD & \\
\hline & SD & $1(7,7 \%)$ \\
\hline & SMP & $6(46,2 \%)$ \\
\hline & SMA & $5(38,5 \%)$ \\
\hline & Grade CHF & \\
\hline & II & $4(30,8 \%)$ \\
\hline & III & $9(69,2 \%)$ \\
\hline
\end{tabular}

Dari tabel 1 diketahui umur responden rata-rata 54,23 tahun dengan standar deviasi 5,8 tahun, jenis kelamin sebagian besar lakilaki 8 orang $(61,5 \%)$, pendidikan sebagian besar SMP 6 orang (46,2\%), dan sebagian besar pada grade NYHA III 9 orang $(69,2 \%)$.

Tabel 2

Tabel 3

Tabel 4

\section{PEMBAHASAN}

Oedema kaki pada pasien CHF lebih sering terjadi pada pasien dengan kelemahan jantung akibat adanya akumulasi cairan di kaki dan tungkai yang di akibatkan oleh ekspansi volume interstisial atau peningkatan volume ekstraseluler (Cho and Atwood, 2002). Semakin besar oedema kaki, maka menunjukan bahwa penyakit CHF yang diderita pasien sudah cukup lama (Trayes et al., 2013; Rahnavard, Nodeh and Hatamipour, 2014). Sehinga perlu tatalaksana yang lebih kompleks dan lebih banyak intervensi lainnya (Chatterjee, 2002).

Cairan tubuh yang berada di ekstraseluler mengalami peningkatan jumlahnya, yang diakibatkan oleh perubahan dalam keseimbangan tekanan hidrostatik dan tekanan onkotik. Akibat ketidakseimbangan tersebut menyebabkan kedua kompartemen cairan tubuh terganggu dalam lintasan cairan antar kompartemen tersebut. Untuk mengatasi gangguan pintasan cairan dalam kedua kompartemen tersebut perlu perbaikan keseimbangan yang melibatkan tekanan hidrostatik, onkotik, plasma, permeabilitas dan dinding pembuluh (Cho and Atwood, 2002; Kasron and Engkartini, 2018; Kasron, 2019)

Oedem kaki secara umum dapat dikurangi dengan melakukan penatalaksanaan elevasi kaki, dimana elevasi kaki akan menstimulasi pengeluaran cairan melalui saluran limfe ke bagian yang lebih proksimal, sehingga menurunkan kejadian oedema kaki (Ciocon, Galindo-Ciocon and Galindo, 1995; Ely et al., 2006). Penatalaksanaan foot elevation adalah teknik menggunakan gaya gravitasi untuk menurunkan aliran darah ke area oedema kaki dan meningkatkan aliran darah dan cairan yang menuju ke jantung. Proses elevasi kaki menstimulasi pengeluaran cairan melalui saluran limfe ke bagian yang lebih proksimal, sehingga menurunkan kejadian oedema kaki (Vesely, Quinn and Pine, 2013). Foots elevation (FE) merupakan intervensi yang mudah dan sederhana yang dapat dilakukan untuk mengurangi gejala FO. Dengan memberikan posisi kaki dinaikan akan meningkatkan jumlah volume dan aliran darah dan limfe kembali ke jantung (Man et al., 2004). Demikian juga dengan memberikan FE akan meningkatkan sirkulasi aliran darah pada pembuluh kapiler bagian distal yang akan meningkatkan aliran darah ke bagian tubuh. (Park, Han and Kim, 2010)

Hasil penelitian ini menunjukan pada kelompok intervensi saat hari pertama menunjukan tidak terdapat perbedaan FO pada kaki kanan sedangkan pada kaki kiri menunjukan ada perbedaan yang bermakna. Berbeda dengan kelompok kontrol yang menunjukan tidak ada perbedaan yang bermakna pada proses 
FE sebelum dan setelah FE pada hari pertama FE. Hal tersebut menunjukan bahwa ada pengaruh proses FE terhadap tingkat oedema kaki pada pasien, namun hanya pada kaki bagian kiri saja, hal tersebut dimungkinkan karena kaki kiri semua responden adalah anggota gerak yang tidak dominan sehingga lebih mudah untuk mengalami penurunan FO. Hal tersebut mungkin akan berbeda bila responden lebih dominan menggunakan anggota gerak sebelah kiri (kidal) maka proses FE akan kurang berpengaruh. Serta juga pada kaki kiri pada area lingkar ankle lebih cepat mengalami penurunan oedema kaki dimungkinkan terjadi karena pada saluran pembuluh limfe pada area distal lebih mudah untuk mengembang atau dilatasi karena proses FE. Serta disebabkan secara umum pada responden ekstremitas bawah kiri kurang dominan dalam melakukan aktivitas keseharian, sehingga ektremitas bawah kiri secara anatomi lebih kecil dibandingakan ekstremitas bawah kanan.

Hasil penelitian saat hari kedua pada kelompok intervensi menunjukan bahwa semua FO dibandingkan pada hari pertama menunjukan terdapat perbedaan FO baik pada lingkar ankle, instep maupun MP joint, baik pada kaki kanan maupun pada kaki kiri dengan $p$-value $<0,001$. Demikian juga pada hari ketiga, hasil penelitian menunjukan bahwa semua FO dibandingkan pada hari kedua menunjukan terdapat perbedaan semua FO baik, baik pada kaki kanan maupun pada kaki kiri dengan p-value $<0,001$. Demikian juga pada hari ketiga, hasil penelitian menunjukan bahwa semua FO dibandingkan pada hari pertama menunjukan terdapat perbedaan FO dengan $p$-value <0,001. Hampir sama dengan kelompok kontrol yang menunjukan ada perbedaan yang bermakna antara hari pertama dengan hari kedua, namun tidak ada perbedaan yang bermakna antara hari kedua dengan hari ketiga. Sedangkan secara umum hari pertama dan hari ketiga terdapat perbedaan yang bermakna yang menunjukan adanya penurunan oedema kaki.

Secara umum menunjukan pada kelompok kontrol maupun intervensi mengalami penurunan FO pada hari ketiga. Serta hasil perbandingan selisih antara pengukuran FO pada hari pertama dengan kari ketiga pada kedua kelompok antara kelompok kontrol dan intervensi dalam semua FO menunjukan ada perbedaan yang bermakna pada semua lingkar odema. Hal tersebut menunjukan intervensi $\mathrm{FE}$ bermakna dalam penurunan selisih FO pada pasien.

Dalam penelitian ini, secara statistik dan secara klinis menunjukan ada penurunan dalam FO baik pada kelompok kontrol maupun kelompok intervensi, pada kelompok kontrol menerima terapi medikasi diuretik lasix dan atau furosemide dalam terapi yang diberikannya, bisa dimungkinkan penurunan oedema tersebut akibat efek dari pemberian medikasi tersebut, seperti penelitian Fogari (2005), menunjukan bahwa pasien yang mengalami eodema dapat diberikan terapi diuretik untuk menurunkan oedema tersebut (Fogari, 2005), sedangkan pada kelompok intervensi selain menerima medikasi diuretik juga mendapat terapi $\mathrm{FE}$ sehingga mengalami penurunan oedema yang lebih cepat dibandingkan pada kelompok kontrol yang dapat dilihat dari angka penurunan FO dan juga selisih FO pertama sebelum intervensi dengan hari ketiga pengukuran. yang lebih besar serta penurunan yang signifikan pada hari pertama FE, hari kedua dan hari ketiga FE. 
Pada kasus oedema kaki akibat limfadema juga dapat dilakukan proses FE seperti penelitian yang dilakukan oleh (Kriederman et al., 2002) tentang efektifitas penggunaan pijat dan atau juga penggunaan penekan (bandage/compression) mampu mengurangi jumlah cairan pada kondisi limfedema. (Kriederman et al., 2002)

Proses FE dapat meningkatkan aliran darah sekaligus meningkatkan aliran sirkulasi limfatik pada jaringan tersebut. Proses FE dengan penekanan akan mengenai pembuluh darah, pada pembuluh darah tersebut akan tertekan dan terdorong dengan proses $\mathrm{FE}$, sehingga aliran darah akan menuju ke bagian yang lebih proksimal, demikian juga akan terjadi permeabilitas dinding pembuluh darah (Goats, 1994). Demikian juga pada pembuluh limfe, dengan proses FE tersebut akan merangsang aliran cairan dari bagian interstisial sel akan menuju ke bagian dalam pembuluh limfe yang selanjutnya akan di alirkan ke bagian proskimal pada pembuluh limfe tersebut. Selanjutnya cairan akan dibawa kembali ke sistem vaskuler di muara saluran limfe di atrium dextra jantung (Ekici et al., 2009).

Hasil penelitian menunjukan terdapat perubahan FO pada pasien CHF yang mengalami oedema kaki setelah diberikan intervensi $\mathrm{FE}$ setelah intervensi FE pada hari pertama, kedua dan ketiga dengan $p$ value $<0,001$. Serta terdapat perbedaan selisih FO pada pengukuran sebelum intervensi dengan pengukuran pada hari ketiga intervensi yang sangat signifikan antara kelompok kontrol dan kelompok intervensi.

\section{E. KESIMPULAN DAN SARAN}

Berdasarkan hasil penelitian menunjukan bahwa bahwa foot elevation efektif untuk menurunkan oedema kaki pada pasien $\mathrm{CHF}$ pada hari pertama, kedua dan hari ketiga dengan $p$-value $<0,001$. Serta terdapat perbedaan selisih FO pada pengukuran sebelum foot elevation dengan hari ketiga foot elevation. Sehingga perawat dapat melakukan intervensi elevasi kaki pada pasien CHF untuk mengurangi oedema kaki.

\section{DAFTAR PUSTAKA}

Chatterjee, K. (2002) 'Congestive Heart Failure What Should Be the Initial Therapy and Why?', American Journal Cardiovascular Drugs, 2(1), pp. 1-6.

Cho, S. and Atwood, J. E. (2002) 'Peripheral edema', American Journal of Medicine, 113(7), pp. 580-586. doi: 10.1016/S00029343(02)01322-0.

Ciocon, J. O., Galindo-Ciocon, D. and Galindo, D. J. (1995) 'Raised leg exercises for leg edema in the elderly.', Angiology, 46(1), pp. 1925. doi:

$10.1177 / 000331979504600103$.

Desai, A. S., Lewis, E. F., Li, R. and Solomon, S. D. (2012) 'Rationale and design of the Treatment of Preserved Cardiac Function Heart Failure with an Aldosterone Antagonist Trial: A randomized, controlled study of spironolactone in patients with symptomatic heart failure and preserved ejection fraction', American Heart Journal. Mosby, Inc., 162(6), p. 966-972.e10. doi: 10.1016/j.ahj.2011.09.007.

Dinas Kesehatan Republik Indonesia (2013) 'Riset Kesehatan Dasar 2013', Riset Kesahatan Dasar, pp. 
111-116. doi: 1 Desember 2013.

Ekici, G., Bakar, Y., Akbayrak, T. and Yuksel, I. (2009) 'Comparison of Manual Lymph Drainage Therapy and Connective Tissue Massage in Women With Fibromyalgia: A Randomized Controlled Trial', Journal of Manipulative and Physiological Therapeutics. National University of Health Sciences, 32(2), pp. 127-133. doi: 10.1016/j.jmpt.2008.12.001.

Ely, J. W., Osheroff, J. a., Chambliss, M. L. and Ebell, M. H. (2006) 'Approach to Leg Edema of Unclear Etiology', The Journal of the American Board of Family Medicine, 19(2), pp. 148-160. doi: 10.3122/jabfm.19.2.148.

Fogari, R. (2005) 'Ankle oedema and sympathetic activation.', Drugs, 65 Suppl 2, pp. 21-7. doi: 10.2165/00003495-200565002-00004.

Goats, G. (1994) 'Massage - the scientific basis of an ancient art: part 2 . Physiological and therapeutic effects', BJSM: Britain Journal Specials Medicine, 2(28), pp. 153-156.

Kasron, K. (2019) 'PIJAT KAKI EFEKTIF MENURUNKAN FOOT EDEMA PADA PENDERITA CONGESTIVE HEART FAILURE (CHF)', Jurnal Ilmu Keperawatan Medikal Bedah, 2(1), pp. 14-26.

Kasron and Engkartini (2018) 'Pijat Kaki untuk Menurunkan Foot Oedema pada Penderita Congestive Heart Failure', in Priyanto and Widodo, G. G. (eds) Update on Management of Cardiac Arrythmias. Kabupaten Semarang: Fakultas Keperawatan Universitas Ngudi Waluto, pp. 56-67.
Kriederman, B., Myloyde, T., Bernas, M., Preciado, S., Lynch, M., Summers, P., C, W. and Mitte, M. (2002) 'LIMB VOLUME REDUCTION AFTER PHYSICAL TREATMENT BY COMPRESSION AND / OR MASSAGE IN A RODENT MODEL OF PERIPHERAL LYMPHEDEMA', Lymphology, 35, pp. 23-27.

Man, I. O. W., Glover, K., Nixon, P., Poyton, R., Terre, R. and Morrissey, M. C. (2004) 'Effect of body position on foot and ankle volume in healthy subjects.', Clinical physiology and functional imaging, 24(6), pp. 323-6. doi:

$10.1111 / \mathrm{j} .1475-$ 097X.2004.00578.x.

Panel, P., Robert, A., Moe, G. W., Cochair, F., Cheung, A., Costigan, J., Ducharme, A., Estrella-holder, E., Ccn, C., Ezekowitz, J. A., Floras, J., Giannetti, N., Grzeslo, A., Harkness, K., Heckman, G. A., Howlett, J. G., Kouz, S., Leblanc, K., Pharmd, A., Mann, E., Meara, E. O., Rajda, M., Rao, V., Simon, J., Uk, M., Swiggum, E., Ashton, T., Astous, M. D., Dorian, P., Haddad, H., Isaac, D. L. and Leblanc, M. (2011) 'The 2011 Canadian Cardiovascular Society Heart Failure Management Guidelines Update: Focus on Sleep Apnea , Renal Dysfunction , Mechanical Circulatory Support , and Palliative Care', CJCA. Elsevier Inc., 27(3), pp. 319-338. doi: 10.1016/j.cjca.2011.03.011.

Park, D. J., Han, S. K. and Kim, W. K. (2010) 'Is the foot elevation the optimal position for wound healing 
of a diabetic foot?', British Journal of Plastic Surgery. Elsevier Ltd, 63(3), pp. 561-564. doi:

10.1016/j.bjps.2008.11.042.

Pozehl, B., Duncan, K., Hertzog, M. and Norman, J. F. (2010) 'Heart Failure Exercise And Training Camp: Effects of a multicomponent exercise training intervention in patients with heart failure', Heart \& Lung: The Journal of Acute and Critical Care. Elsevier Inc., 39(6), pp. S1-S13. doi: 10.1016/j.hrtlng.2010.04.008.

Rahnavard, Z., Nodeh, Z. H. and Hatamipour, K. (2014) 'Congestive heart failure: Predictors of healthrelated quality of life in Iranian women.', Contemporary Nurse, 47(12), pp. 159-167.

Trayes, K. P., Studdiford, J. S., Jefferson, T., Tully, A. S. and Clinic, C. (2013) 'Edema: Diagnosis and Management'.

Vesely, J., Quinn, T. and Pine, D. (2013) 'A Resource for Interprofessional Providers Pedal Edema in Older Adults', Arizona medicine, (July), pp. 28-31.

World Health Organization (WHO) (2015) 'Indonesia: WHO statistical profile', Country statistics and global health estimates. Available at: http://who.int/gho/mortality_burden_di sease/en/. 
Tabel 2

Lingkar Oedem Kaki Kelompok Kontrol dan Intervensi

\begin{tabular}{|c|c|c|c|c|c|c|c|c|}
\hline No & $\begin{array}{c}\text { Kelompok/ } \\
\text { Kaki }\end{array}$ & Pengukuran & $\mathbf{L}$ & LO & $\mathbf{L}$ & LO & $\mathbf{L}$ & LO \\
\hline \multirow[t]{14}{*}{1} & Kontrol/ & Pre 0 & Angkle & $27,7 \pm 1,7$ & Instep & $27,6 \pm 1,7$ & MP & $27,1 \pm 1,5$ \\
\hline & Kanan & Post 1 & & $27,7 \pm 1,6$ & & $27,6 \pm 1,6$ & & $27,1 \pm 1,5$ \\
\hline & & Post 2 & & $27,5 \pm 1,6$ & & $27,4 \pm 1,7$ & & $26,7 \pm 1,5$ \\
\hline & & Post 3 & & $27,3 \pm 1,6$ & & $27,1 \pm 1,6$ & & $26,5 \pm 1,6$ \\
\hline & & $\Delta 1$ & & $0,02 \pm 0,33$ & & $-(0,01 \pm 0,16)$ & & $0,02 \pm 0,04$ \\
\hline & & $\Delta 2$ & & $0,16 \pm 0,23$ & & $0,19 \pm 0,24$ & & $0,32 \pm 0,14$ \\
\hline & & $\Delta 3$ & & $0,03 \pm 0,33$ & & $0,10 \pm 0,25$ & & $0,31 \pm 0,33$ \\
\hline & Intervensi/ & Pre 0 & Angkle & $27,8 \pm 1,8$ & Instep & $27,7 \pm 1,7$ & MP & $27,2 \pm 1,6$ \\
\hline & Kanan & Post 1 & & $27,8 \pm 1,6$ & & $27,6 \pm 1,8$ & & $27,2 \pm 1,6$ \\
\hline & & Post 2 & & $27,5 \pm 1,6$ & & $27,4 \pm 1,7$ & & $26,9 \pm 1,6$ \\
\hline & & Post 3 & & $27,2 \pm 1,7$ & & $27,0 \pm 1,7$ & & $26,5 \pm 1,7$ \\
\hline & & $\Delta 1$ & & $0,02 \pm 0,33$ & & $-(0,01 \pm 0,16)$ & & $0,02 \pm 0,05$ \\
\hline & & $\Delta 2$ & & $0,23 \pm 0,29$ & & $0,30 \pm 0,18$ & & $0,37 \pm 0,10$ \\
\hline & & $\Delta 3$ & & $0,52 \pm 0,31$ & & $0,65 \pm 0,17$ & & $0,77 \pm 0,17$ \\
\hline \multirow[t]{14}{*}{2} & Kontrol/ & Pre 0 & Angkle & $27,6 \pm 1,7$ & Instep & $27,7 \pm 1,6$ & MP & $27,0 \pm 1,6$ \\
\hline & Kiri & Post 1 & & $27,7 \pm 1,6$ & & $27,6 \pm 1,7$ & & $26,8 \pm 1,7$ \\
\hline & & Post 2 & & $27,4 \pm 1,7$ & & $27,3 \pm 1,7$ & & $26,4 \pm 1,7$ \\
\hline & & Post 3 & & $27,1 \pm 1,7$ & & $27,1 \pm 1,8$ & & $26,2 \pm 1,7$ \\
\hline & & $\Delta 1$ & & $-(0,01 \pm 0,14)$ & & $0,05 \pm 0,23$ & & $0,24 \pm 0,58$ \\
\hline & & $\Delta 2$ & & $0,28 \pm 0,13$ & & $0,36 \pm 0,23$ & & $0,37 \pm 0,45$ \\
\hline & & $\Delta 3$ & & $0,29 \pm 0,26$ & & $0,29 \pm 0,32$ & & $0,48 \pm 0,53$ \\
\hline & Intervensi/ & Pre 0 & Angkle & $27,8 \pm 1,7$ & Instep & $27,7 \pm 1,6$ & MP & $27,1 \pm 1,5$ \\
\hline & Kiri & Post 1 & & $27,7 \pm 1,6$ & & $27,7 \pm 1,6$ & & $26,9 \pm 1,6$ \\
\hline & & Post 2 & & $27,5 \pm 1,6$ & & $27,3 \pm 1,6$ & & $26,6 \pm 1,6$ \\
\hline & & Post 3 & & $27,2 \pm 1,6$ & & $26,9 \pm 1,6$ & & $26,3 \pm 1,6$ \\
\hline & & $\Delta 1$ & & $0,03 \pm 0,05$ & & $0,02 \pm 0,04$ & & $0,14 \pm 0,42$ \\
\hline & & $\Delta 2$ & & $0,27 \pm 0,13$ & & $0,37 \pm 0,13$ & & $0,48 \pm 0,39$ \\
\hline & & $\Delta 3$ & & $0,59 \pm 0,18$ & & $0,72 \pm 0,13$ & & $0,74 \pm 0,41$ \\
\hline
\end{tabular}

Ket: L: Lingkar; LO: Lingkar Oedema; $\Delta 1$ : Pre 0-Post1; $\Delta 2$ : Pre 0-Post2; $\Delta 3$ : Pre 0-Post3

Tabel 3

Analisis Perbandingan Lingkar Oedema Pada Kelompok Kontrol Dan Intervensi

\begin{tabular}{|c|c|c|c|c|c|c|c|c|}
\hline No & Kelompok /Kaki & Perbandingan & $\mathbf{L}$ & p-value* & $\mathbf{L}$ & $p$-value* & $\mathbf{L}$ & $p$-value* \\
\hline \multirow[t]{8}{*}{1} & Kontrol & Pre 0 vs Post 1 & Angkle & 0,206 & Instep & 0,317 & MP & 0,046 \\
\hline & /Kanan & Post 1 vs Post 2 & & $<0,001$ & & 0,006 & & $<0,001$ \\
\hline & & Post 2 vs Post 3 & & 0,021 & & 0,130 & & 0,924 \\
\hline & & Post 1 vs Post 3 & & 0,491 & & 0,081 & & 0,001 \\
\hline & Intervensi/ & Pre 0 vs Post 1 & Angkle & 0,205 & Instep & 0,206 & MP & 0,059 \\
\hline & Kanan & Post 1 vs Post 2 & & $<0,001$ & & $<0,001$ & & $<0,001$ \\
\hline & & Post 2 vs Post 3 & & $<0,001$ & & $<0,001$ & & $<0,001$ \\
\hline & & Post 1 vs Post 3 & & $<0,001$ & & $<0,001$ & & $<0,001$ \\
\hline \multirow[t]{4}{*}{2} & Kontrol/ & Pre 0 vs Post 1 & Angkle & 0,493 & Instep & 0,301 & MP & 0,007 \\
\hline & Kiri & Post 1 vs Post 2 & & $<0,001$ & & $<0,001$ & & 0,009 \\
\hline & & Post 2 vs Post 3 & & 0,937 & & 0,326 & & 0,325 \\
\hline & & Post 1 vs Post 3 & & 0,001 & & 0,002 & & 0,001 \\
\hline
\end{tabular}




\begin{tabular}{|c|c|c|c|c|c|c|c|}
\hline \multirow{4}{*}{$\begin{array}{l}\text { Intervensi/ } \\
\text { Kiri }\end{array}$} & Pre 0 vs Post 1 & Angkle & 0,008 & Instep & 0,046 & MP & 0,017 \\
\hline & Post 1 vs Post 2 & & $<0,001$ & & $<0,001$ & & $<0,001$ \\
\hline & Post 2 vs Post 3 & & $<0,001$ & & $<0,001$ & & $<0,001$ \\
\hline & Post 1 vs Post 3 & & $<0,001$ & & $<0,001$ & & $<0,001$ \\
\hline
\end{tabular}

Ket: L: Lingkar; *: Uji Wilcoxon, bermakna pada p-value $<0,05$.

Tabel 4

Analisis Perbandingan Lingkar Oedema Pada Kelompok Kontrol dan Intervensi

\begin{tabular}{|c|c|c|c|c|c|c|c|c|}
\hline No & Kaki & Pengukuran & $\mathbf{L}$ & p-value* & $\mathbf{L}$ & $p$-value $*$ & $\mathbf{L}$ & p-value* \\
\hline \multirow[t]{7}{*}{1} & Kanan & Pre 0 & Angkle & 0,777 & Instep & 0,814 & MP-Joint & 0,814 \\
\hline & & Post 1 & & 0,832 & & 0,813 & & 0,832 \\
\hline & & Post 2 & & 0,934 & & 0,777 & & 0,962 \\
\hline & & Post 3 & & 0,274 & & 0,324 & & 0,473 \\
\hline & & $\Delta \mathrm{A} 1$ & & 0,960 & & 0,757 & & 0,944 \\
\hline & & $\Delta \mathrm{A} 2$ & & 0,175 & & 0,057 & & 0,201 \\
\hline & & $\Delta \mathrm{A} 3$ & & $<0,001$ & & $<0,001$ & & $<0,001$ \\
\hline \multirow[t]{7}{*}{2} & Kiri & Pre 0 & Angkle & 0,759 & Instep & 0,814 & MP-Joint & 0,925 \\
\hline & & Post 1 & & 0,804 & & 0,832 & & 0,732 \\
\hline & & Post 2 & & 0,778 & & 0,906 & & 0,814 \\
\hline & & Post 3 & & 0,630 & & 0,417 & & 0,597 \\
\hline & & $\Delta \mathrm{A} 1$ & & 0,676 & & 0,926 & & 0,461 \\
\hline & & $\Delta \mathrm{A} 2$ & & 0,816 & & 0,990 & & 0,130 \\
\hline & & $\Delta \mathrm{A} 3$ & & $<0,001$ & & $<0,001$ & & 0,011 \\
\hline
\end{tabular}

Ket: $\Delta$ 1: Pre 0-Post1; $\Delta 2$ : Pre 0-Post2; $\Delta 3$ : Pre 0-Post3; *: Uji Mann-Whitney, bermakna pada pvalue $<0,05$. 